\title{
A LAGRANGIAN APPROACH FOR INVESTIGATING ANOMALIES IN THE MOISTURE TRANSPORT DURING DROUGHT EPISODES
}

\author{
A. DRUMOND ${ }^{1 *}$, R. NIETO $^{1,2}$, L. GIMENO ${ }^{1}$ \\ ${ }^{1}$ Environmental Physics Laboratory (EPhysLab), Faculdade de Ciencias, Universidad de Vigo, Ourense, Spain. \\ ${ }^{2}$ Department of Atmospheric Sciences, Institute of Astronomy, \\ Geophysies and Atmospheric Sciences, University of São Paolo, Brazil.
}

\begin{abstract}
The present work proposes a Lagrangian diagnostic scheme to investigate the anomalous moisture transport before, during, and after the occurrence of drought episodes. The Lagrangian approach proposed here uses the model FLEXPART integrated with the ERA-Interim data set and it has been successfully applied in previous studies concerning the climatological characterization of the sources and sinks of moisture in several regions around the world. The drought episodes will be identified and characterized through the SPEI index. The anomalies of the moisture sources for the area affected will be analyzed, as well as the impact of the droughts on the moisture transport from the area affected towards its climatological sinks (previous studies suggest that some heat wave episodes can be associated with anomalies in moisture transport). In other words, the methodology proposes to investigate the role of the area affected as a receptor/source of moisture during the drought episodes. As an example of applicability of the methodology, the severe drought episode over central U.S. in 2012 is analyzed. An analysis of the 2012 anomalies suggests that there was some reduction in the contribution from the local and continental climatological moisture sources for the central U.S. mainly from June to October. The period from July to October 2012 was also characterized by the reduction of the moisture transport from the drought area towards its climatological sinks located over northeastern North America. A better understanding not only of the transport of humidity, but also of the relationship between sources/sinks of moisture and of possible impacts generated by variations in the sources is crucial for a more accurate weather forecast, helping to minimize the consequences of the natural hazards.
\end{abstract}

Una aproximación lagrangiana para investigar anomalías en el transporte de humedad durante episodios de sequía

RESUMEN. El presente trabajo propone un método de diagnóstico lagrangiano para la investigación del transporte anómalo de humedad antes, durante y después de la ocurrencia de episodios de sequía. La técnica lagrangiana propuesta usa el modelo FLEXPART alimentado con los datos del reanálisis ERA-Interim y 
ha sido aplicado en diversos estudios previos con éxito para la caracterización climatológica de fuentes y sumideros de humedad en distintas regiones del planeta. Se utiliza el índice SPEI para la identificación y caracterización de los episodios de sequía. Se analizan las anomalías en las fuentes de humedad para el área afectada, así como el impacto de las sequías en el transporte de humedad desde esa área definida hacia sus sumideros climatológicos (estudios anteriores sugieren que algunos episodios de olas de calor pueden estar asociados con anomalías en el transporte de humedad). En otras palabras, la metodología consiste en investigar el rol del área afectada como receptor/fuente de humedad en los episodios. Como un ejemplo de aplicación del método, se analiza el intenso episodio de sequía ocurrido en la región central de E.E.U.U. durante 2012. El análisis de las anomalías en 2012 sugiere la reducción en la contribución de las fuentes de humedad local y continental climatológicas para el centro del E.E.U.U. particularmente desde Junio hasta Octubre. El período desde Julio hasta Octubre de 2012 ha sido igualmente caracterizado por la reducción del transporte de humedad desde la región de la sequía hacia sus sumideros climatológicos en noreste de Norte América. Un mayor entendimiento, no solamente del transporte de humedad, sino también de la relación entre fuentes y sumideros y de los probables impactos generados por las variaciones en las fuentes es crucial para una predicción del tiempo y del clima con más calidad, ayudando a minimizar las consecuencias de los desastres naturales.

Key words: moisture transport, drought, Lagrangian approach.

Palabras clave: transporte de humedad, sequias, método Lagrangiano.

Received 30 December 2015

Accepted 2 February 2016

*Corresponding author: A. Drumond, Environmental Physics Laboratory (UVIGOCSIC), Departamento de Física Aplicada, Facultad de Ciencias, Universidade de Vigo, Campus As Lagoas, s/n, 32004-Ourense, Spain. E-mail: anitadru@uvigo.es

\section{Introduction}

The understanding of the hydrological cycle in terms of intensity and variability has become one of the most important themes for geosciences due to its direct association with questions concerning climate variability and climate change. It is known that the origins of the precipitation over a region can be: a) the local atmospheric humidity; b) the humidity advection into the region by the winds; and c) recycling (Brubaker et al., 1993). Previous studies (e.g. Trenberth and Guillemot, 1998) pointed out the importance of the moisture transport and its convergence in low atmospheric levels for the occurrence of intense precipitation. Thus, the identification of the moisture sources is crucial for a better understanding of the precipitation. 
There are different methods used to establish source-sink relationships for atmospheric water vapour, and a detailed intercomparison of them is discussed by Gimeno et al. (2012). The most recently developed Lagrangian techniques are being extensively applied for evaluating the origin of the water precipitating in a target area because this approach provides more realistic traces of air parcels in comparison to the Eulerian approaches, enabling the trajectories to be followed and sourcereceptor relationships to be established. (e.g. Stohl and James, 2004, 2005; Dirmeyer and Brubaker, 2007; Sodemann et al., 2008; Gimeno et al., 2013; Knippertz et al., 2013).

Recently the Lagrangian diagnostic scheme of Stohl and James $(2004,2005)$ has been applied in several studies to investigate not only the climatological moisture transport at global (e.g. Gimeno et al., 2010, 2013) and regional scales (e.g. Nieto et al., 2006; Drumond et al., 2008, 2010, 2014), but also the role of the climate variability modes over the sources (Castillo et al., 2014; Nieto et al., 2014). However, the role of anomalous moisture transport on the extreme meteorological events, such as episodes of drought or intense precipitation, has been poorly explored through a Lagrangian perspective.

In a rough way, drought may be defined as a period of deficient precipitation with possible impacts on agriculture, water resources, natural ecosystems and several economic activities such as tourism, industry and even the urban supply. Despite the apparent simplicity of its definition, understanding, monitoring and mitigating drought is a very difficult task as a consequence of the intrinsic nature of the phenomenon (Vicente-Serrano, 2004). Given the difficulties to identify the onset and end of a drought in an objective way, and to quantify drought severity in terms of its duration, magnitude, and spatial extent, much effort has been devoted to developing drought indicators for risk analysis and drought monitoring. The Standardized Precipitation Evapotranspiration Index (SPEI) was recently developed (Vicente-Serrano et al., 2010) to overcome the limitations of the two most widely used indicators: the Palmer Drought Severity Index (PDSI) (Palmer, 1965) and the Standardized Precipitation Index (SPI) (McKee et al., 1993). SPEI combines the sensitivity of PDSI to changes in evaporation demand caused by temperature with the multi-temporal nature of the SPI.

Investigating the physical causes of the drought can be considered a hard task because the episode may be defined in different time-scales. Most of the meteorological analyses of droughts have been focused on anomalous boundary conditions, such as the Sea Surface Temperature (SST), which can modulate the atmospheric circulation and the atmospheric stability (e.g. Feng et al., 2010). There are few studies focusing on the anomalous transport of moisture during drought episodes (e.g. Kam et al., 2014; Dirmeyer et al., 2014). Thus, a further reason for understanding the source-to-sink relationships in the atmospheric water cycle lies in the role they play in the extreme weather events. Persistence of droughts could be due, in part, to the anomalies in the transport of moisture (Seneviratne et al., 2006; Trigo et al., 2013). 
During the twentieth century the tendency towards drier conditions prevailed over large part of the European continent (e.g. Sousa et al., 2011). The onset of the 21 st century has been characterized by the occurrence of severe and long drought episodes. For example, the mega-event in U.S. included shorter episodes (2002, 2003, 2007, and 2009), and the low values of the precipitation accumulated enhanced higher temperatures, increased the evapotranspiration and decreased the runoff (MacDonald, 2010). The absence of soil moisture associated with drought processes may be the cause of heat waves in the sink areas of the moisture transported from the region of the drought (e.g. Miralles et al., 2014). It confirms the importance in also investigating the anomalies in the regions that receive moisture from the areas characterized by the drought episodes.

The aim of the present work is to propose an innovative Lagrangian diagnostic methodology for investigating anomalous moisture transport associated with drought episodes. Once the area affected by the drought is identified through the SPEI index, an analysis of anomalies in the moisture transport towards and from this region may be carried out in order to verify possible changes in the moisture sources associated with the occurrence of the episode, as well as the impact of the drought over the moisture transported from the area affected. Data and methodology are explained in section 2 , and an example of application of the method is presented in the section 3 with the case study of the 2012 U.S. drought. Section 4 summarizes the methodology and its applications.

\section{Data and Method}

The drought episodes are identified through the SPEI index. For this work we use the data from the Global SPEI database (http://sac.csic.es/spei/database.html), with a 0.5 degrees spatial resolution and a monthly time resolution. SPEI time-scales between 1 and 48 months are provided, allowing the identification of different drought types. The calibration period for this SPEI dataset is January 1901 to December 2014. In this work, the area affected by the drought conditions is selected considering the grid points presenting SPEI lower than -1.5, the upper limit for the category "severe drought" proposed by McKee et al. (1993) for the SPI index.

The air masses tracks are calculated for the areas affected by the drought conditions through the Lagrangian approach based on the model FLEXPART (Stohl and James, 2004, 2005). In this model, the atmosphere is divided homogeneously into a large number of virtual elements hereafter called "particles" with constant mass $m$. These particles are then advected using 3D winds dataset and superimposed stochastic turbulent and convective motions. For each particle, the increases (through evaporation, $e$ ) and decreases (through precipitation, $p$ ) in moisture along the trajectory can be calculated from changes in $(q)$ with time $e-p=m \mathrm{~d} q / \mathrm{dt}$. When adding $(e-p)$ for all the particles in the atmospheric column over an area $A$, we can obtain the surface freshwater flux $(E-P)$, where $(E)$ is the evaporation and $(P)$ is the precipitation rate per unit area. The method can track $(E-P)$ from any specific region backwards or forwards in time along the trajectories. Drumond et al. (2014) is a recent example of the 
application of backward and forward experiments in the investigation of the moisture transport over the Amazon basin. All particles residing over the target region will be identified every six hours and tracked for 10 days, which is the average time that water vapour resides in the atmosphere (Numaguti, 1999). The total $(E-P)$ integrated over days 1 to 10 is analyzed. Full details of the method and its limitations are described by Stohl and James $(2004,2005)$, and a detailed review of this methodology compared with other approaches developed to study moisture transport was previously provided by Gimeno et al. (2012).

The Lagrangian dataset used in this work comes from a global simulation following the tracks of approximately 2 million particles for a 33 year period (19802012), computed using the FLEXPART v9.0 and the ERA-interim reanalysis data (Dee et al., 2011) available every 6 hours $\left(00,06,12\right.$ and 18 UTC) at a $1^{\circ}$ horizontal resolution on 61 vertical levels (from 0.1 to $1000 \mathrm{hPa}$ ). ERA-Interim may be considered the state-of-the-art reanalysis in terms of hydrological cycle (Trenberth et al., 2011). As stressed by Gimeno et al. (2013), the FLEXPART model requires consistent highquality data for wind and humidity, precluding its application to older reanalysis data (pre-1979), i.e., prior to the significant decrease in the errors in these variables following the inclusion of satellite data (Bengtsson et al., 2004).

The methodology applied here follows Stohl and James (2004; 2005), simply considering the regions of $(E-P)>0((E-P)<0)$ as moisture sources (sinks) and tracking all the air masses reaching (leaving) the area of interest, being or not associated with precipitation events. In the backward analysis, all areas where the particles gained humidity $(E-P>0)$ along their trajectories towards the target area can be considered "sources of moisture". Only regions where $E-P>0$ are considered in the analysis, because they indicate those areas where air particles located within that vertical column, and headed for their target areas, gained moisture. The opposite is valid for the forward analysis, and all areas where the particles lost humidity $(E-P<0)$ along their trajectories from the drought area can be considered "sinks of moisture".

Once defined the area affected by the drought episode, its respective sources of moisture are identified through backward experiment. Anomalies of moisture sources are then calculated by comparing the sources observed during the episode with the climatological (1980-2012) sources for the same target area. In addition, an experiment following the particles from the drought area forward in time allows identifying the respective sinks of moisture. From the comparison with the climatological sinks for the same area one can see which remote regions can be affected by the drought episode in terms of the moisture transport.

A percentile criterion is applied to the climatological July (September) positive (negative) $(E-P)$ field to define a threshold delimiting the spatial extent of the respective sources (sinks) of moisture in the backwards (forwards) experiment. The 95th percentile of the climatological positive (negative) $(E-P)$ values delimits those regions where the air masses were likely to have picked up (lost) a large amount of moisture on their transit towards (from) the drought area. 


\section{An example of applicability of the method: the case study of the 2012 U.S. Drought}

The severe drought experienced in 2012 in central U.S. was characterized by its large extension (the largest since the 1950s) and by the combined deficit of precipitation and high temperatures, which had not been observed since the 1930s. Due to its damages especially in agriculture, this episode has been considered one of the major natural hazards by the U.S. Department of Agriculture. In order exemplify the applicability of the methodology proposed in this work, we consider this event as a case study. It would be important to recall that we are not investigating the physical causes of this episode, we are only taking it as an example to illustrate the method.

The area affected by drought conditions may be visualized in the Figure 1 (left), which shows the SPEI 3-month values obtained for July 2012. Because the episode was more intense during the summer months, we considered the 3-month time scale, centering the analysis in July 2012, when the reports registered the major impacts. In order to study the anomalies in the moisture transport, firstly it is necessary to define the area of drought. We took the value of -1.5 in Fig. 1 (left) (it represents approximately $93 \%$ of the probability density function) to isolate the regions more affected. The choice of the SPEI value is arbitrary, but it represents the threshold for the category of severe droughts proposed by McKee et al. (1993) for the SPI index. The study area is shown in Fig. 1 (right), and it is located over central U.S. This is the area used in the Lagrangean analyses.

Through the backward experiment the climatological sources for the region affected by the drought were identified (warm colors, Fig. 2 top left). Positive (negative) $(E-P)$ values represent regions where $E>P(E<P)$ in the hydrological budget, hereafter called moisture source (sink). Figure 2 (top, right) shows the monthly anomalies of sources (regions presenting positive values of $(E-P)$ integrated over 10-day trajectories) for 2012 July. In this way, positive $(E-P)$ anomalies (pink colors) indicate regions where the sources were intensified during the episode. The opposite is valid for negative values (green colors). Results suggest some reduction of the moisture contribution mainly from the continental regions located in southeastern and western U.S. (green colors).
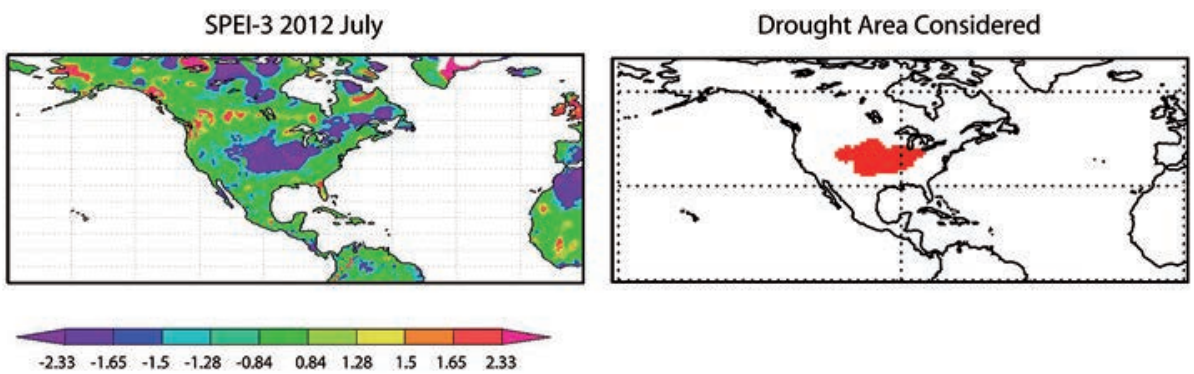

Figure 1. Left: SPEI-3 values for July 2012. Right: the target area considered in the Lagrangian experiments. 
1980/2012 July - 10-d (E-P) from BW exp
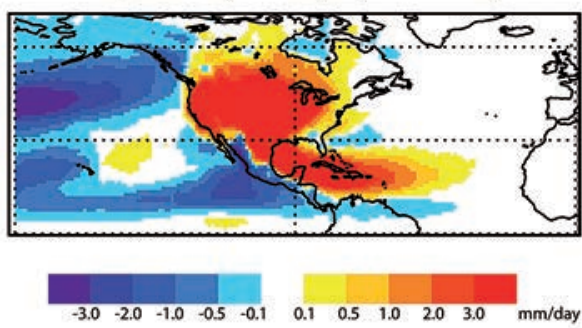

Source - Total

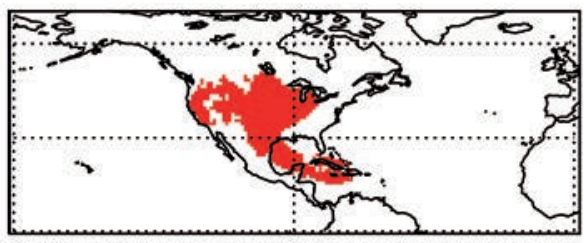

Source - Continental

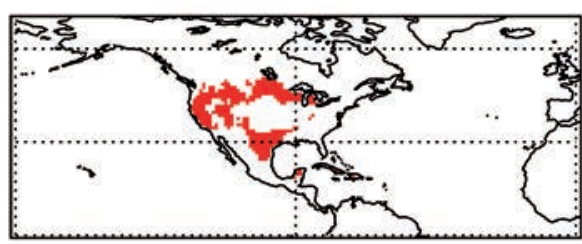

2012 July - Moisture Source Anomalies
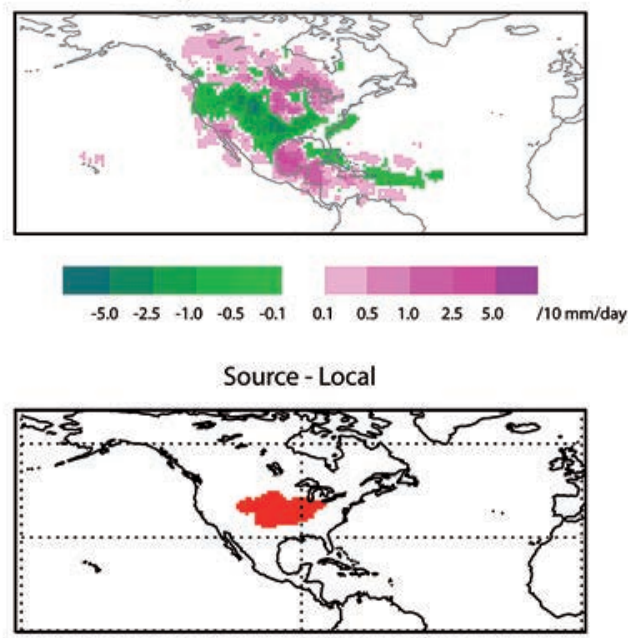

Source-Oceanic

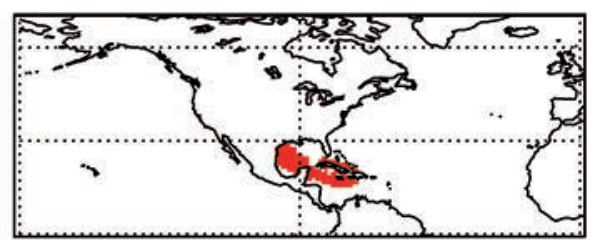

Figure 2. Top: 1980-2012 July (E-P) integrated over 10-day backward trajectories for the drought area (left) ( $\mathrm{mm} /$ day), and the 2012 July source anomalies (right) ( $\mathrm{mm} /$ day); the major source area, defined according to the $95 \%$ percentile of all positive $(E-P)$ values obtained via backward trajectories for the drought area (center-left) and its components local (center-right), continental (bottom-left) and oceanic (bottom-right).

The choice of the $(E-P)$ value acting as a threshold for identification of the most intense sources was based on the map of the 1980-2012 July sources for the drought area (Fig. 2 top left). From this climatological field one can see that the area extending from U.S. towards the Gulf of Mexico is the major source (red colors, positive $E-P$ values) for the drought area in this month. The $(E-P)$ value used as threshold was then defined considering the percentile of $95 \%$ of all positive $(E-P)$ values observed in the climatological field (Fig. 2 top left).

The source area considered in our analyses is shown in Fig. 2 (center-left), and it may be divided into three components: the local (coinciding with the target area), the continental, and the oceanic (Fig. 2 center-right, bottom-left and bottom-right, respectively). If these source areas are kept constant along the year and the climatological monthly $(E-P)$ values are integrated over them, it is possible to verify some increasing in the contribution from these sources particularly between March and November, with 
a peak in July (Fig. 3 left). Results suggest that the local and the continental sources present higher moisture contribution in absolute values (the area of the sources were not taken into account in the calculations) when compared to the oceanic one. A brief look at the 2012 anomalies (Fig. 3 right) suggests that the reduction in the contribution occurred from June to October mainly (negative anomalies in the total contribution). It seems that the reduced contribution from the local and continental sources prevailed in the configuration of the negative anomalies in the total contribution, superposing even the enhanced contribution from the ocean observed in the period.

Annual cycle (E-P) integrated over the sources - Clima

2012 (E-P) anomalies integrated over the sources
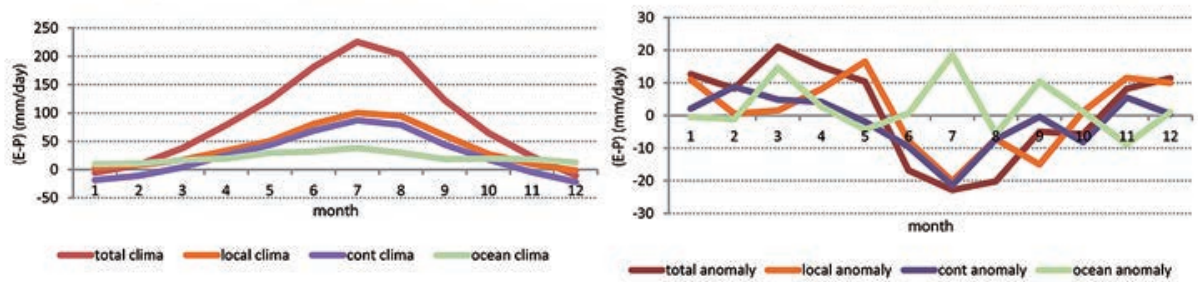

Figure 3. Left: Climatological annual cycle of 10-d (E-P) values integrated over the source and over each one of its three components, defined in Fig. 3 ( $\mathrm{mm} /$ day). Right: the same for left, but for 2012 anomalies ( $\mathrm{mm} /$ day).

The next question would be the possible impacts of the episode over the moisture transported from the drought area towards its climatological sinks. A forward experiment considering the drought area (Fig. 1) as the origin of the air masses was carried out in order to answer it. A visual analysis of the monthly sink anomalies over the continent (Figs. not shown) suggests the predominance of the most intense values in 2012 September, and it was considered as the reference month for the forward analysis. Fig. 4 shows the climatological September sinks and the 2012 sink anomalies (top left and right, respectively). Climatologically, we can see that the major sinks of moisture from the drought region are in northeastern North America, and a large part of this area received less moisture during September 2012 (pink colors represents reduced moisture transport from the drought area).

In this case we are interested in the sink regions affected by the reduced moisture transport from the drought area, and we consider the area of weakened sink anomalies observed in this particular month (Fig. 4 top right, pink colors) intercepted by the September climatological sink (also defined using the 95\% percentile technique) (Fig. 4 top left) as the sink region of interest (Fig. 4 central left). Decomposing the sink into the three components (local, continental and oceanic, Fig. 4 central right, bottom left and right, respectively), climatologically the highest absolute contributions occur from June to September particularly for continental sinks (Fig. 5 left). It is interesting to observe that during 2012 there was some increasing in the moisture contribution during June for the continental sinks considered, but the period from July to October was characterized by the reduction of the transport from the drought area towards the continental and oceanic sinks analyzed (Fig. 5 right). 
1980/2012 Sept - 10-d (E-P) from FF Exp
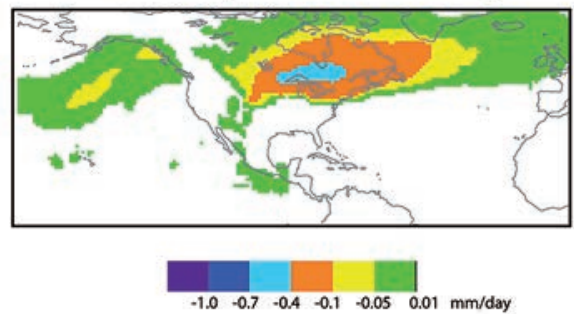

Sink - Total

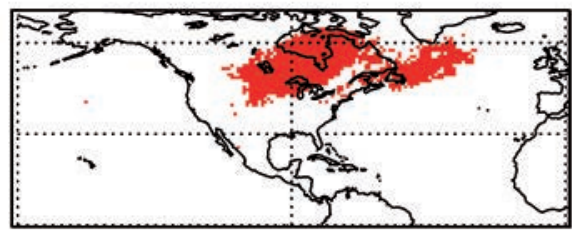

Sink-Continental

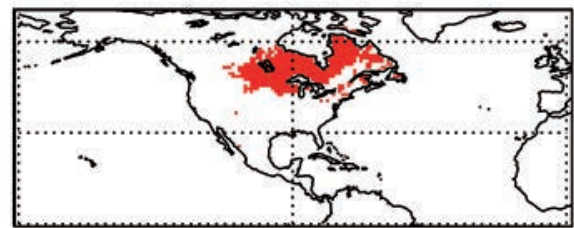

2012 Sept - Moisture Sink Anomalies

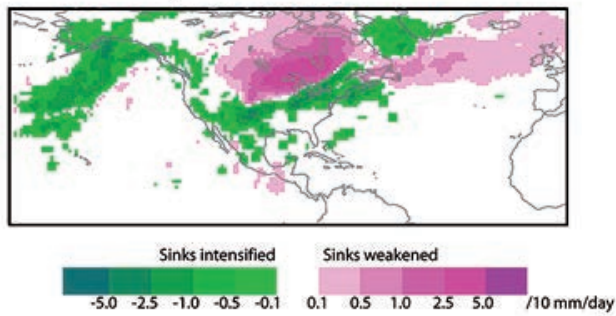

Sink - Local

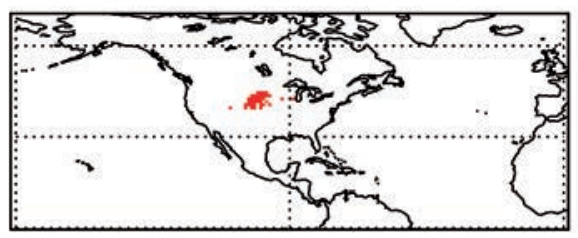

Sink-Oceanic

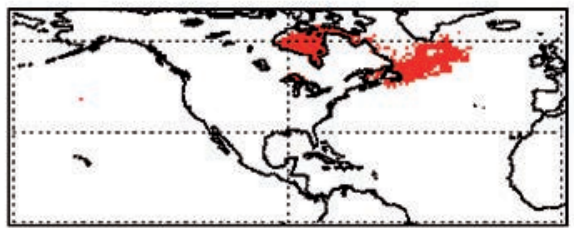

Figure 4. Top: 1980-2012 September (E-P) integrated over 10-day forward trajectories from the drought area (left) ( $\mathrm{mm} /$ day), and the 2012 September sink anomalies (right) (mm/day). Centerleft: the sink area, based on the $95 \%$ percentile of the climatological September $(E-P)$ values and on the 2012 weakened sink anomalies; the sink components: local (center-right), continental (bottom-left) and oceanic (bottom-right).

Annual Cycle of Moisture Contribution for Sinks - Clima

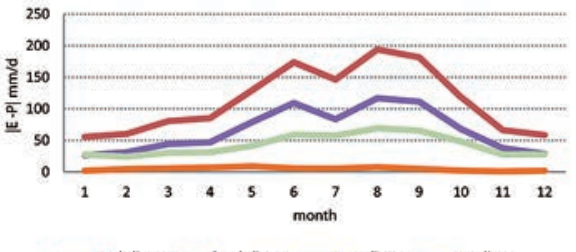

Total dima - Docal clima cont clima oce clima
2012 Anomalous Contribution for Sinks

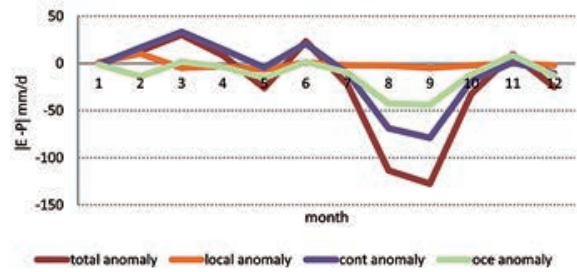

Figure 5. Left: Climatological annual cycle of the moisture contribution from the drought area for the sink area and its three components defined in Fig. 4 ( $\mathrm{mm} /$ day) (values obtained from the

Forward experiment). Right: the same for left, but for the 2012 anomalies (mm/day). 


\section{Summary and Conclusions}

The aim of this work is to present an innovative Lagrangian methodology to investigate anomalies in the moisture transport during the occurrence of drought episodes. The approach consists in applying the method of Stohl and James (2004) together with the Era-Interim data set. The SPEI index is also analyzed in order to characterize the drought episode and to identify the most affected regions.

Basically the method consists in identifying the moisture sources for the area affected by the drought, as well as the source anomalies during the episode, through backward trajectories analysis. The impact of the drought over the moisture transport from the area affected to its climatological sinks is also evaluated through forward experiments. In other words, the methodology consists in investigating the role of the drought area as a sink/source of moisture during the episodes. In order to provide more details about the anomalous patterns, the sinks and sources may be divided into three components: local (area coincides with the region affected by drought), continental and oceanic.

A case study of the 2012 U.S. drought was discussed to illustrate the applicability of the methodology proposed. The region presenting severe drought conditions over central U.S. was identified through the SPEI-3 field for July 2012, and it was the area used in the Lagrangian experiments. From the backward analysis, results suggest that the area extending from U.S. towards the Gulf of Mexico is the major climatological source for the drought area in July. This source region was then separated into three components: the local (coinciding with the target area), the continental, and the oceanic; and their areas were kept constant along the year. A climatological analysis reveals the increasing contribution from these sources particularly between March and November, with a peak in July. In addition, higher moisture contribution comes from the local and continental sources. An analysis of the 2012 anomalies suggests that the reduction in the local and continental contribution occurred mainly from June to October.

In a quite similar way, the impacts of the drought episode over the moisture transport from the area affected towards its climatological sinks were also evaluated through a forward experiment originating in the drought area. It seems that the most intense sink anomalies over the continent occurred in 2012 September, and it was considered as the reference month for the sink analysis. Climatologically, during September the major sinks of moisture from the drought region are in northeastern North America, and the highest absolute contributions particularly for the continental sinks considered occur from June to September. It is interesting to observe that the period from July to October 2012 was characterized by the reduction of the transport from the drought area towards the continental and oceanic sinks analyzed.

We expect to apply this methodology for other severe drought episodes in order to understand the role of the variations in the moisture sources on the development of the drought episodes, as well as the impact of the anomalous moisture transport from drought areas towards their climatological sinks (probably through the occurrence of heat waves episodes). It is the first time that the role of the areas affected by drought 
episodes will be investigated as a receptor/emisor of moisture trough this Lagrangian approach in details. The investigation of the major drought episodes in the globe will allow to identify which mechanisms were more important (variations in the moisture transport from oceanic and land sources) for different regions, and also for the different time-scales considered.

\section{Acknowledgements}

Anita Drumond acknowledges funding by the Spanish Government and FEDER through the SETH (CGL2014-60849-JIN) project. Raquel Nieto acknowledges funding by the Galician Regional Government (Xunta) within the project THIS (EM2014/043), co-funded by FEDER.

\section{References}

Bengtsson, L., Hagemann, S., Hodges, K.I. 2004. Can climate trends be calculated from reanalysis data? Journal of Geophysical Research 109, D11111. Doi: 10.1029/2004JD004536.

Brubaker, K.L., Entekhabi, D., Eagleson, P. 1993. Estimation of continental precipitation recycling. JournalofClimate.6, 1077-1089.Doi: 10.1175/1520-0442(1993)006<1077:EOCPR>2.0.CO;2.

Castillo, R., Nieto, R., Drumond, A., Gimeno, L. 2014. The role of the ENSO cycle in the modulation of moisture transport from major oceanic moisture sources. Water Resources Research 50, 1046-1058. Doi: 10.1002/2013WR013900.

Dee, D.P., Uppala, S.M., Simmons, A.J., Berrisford, P., Poli, P., Kobayashi, S., Andrae, U., Balmaseda, M.A., Balsamo, G., Bauer, P., Bechtold, P., Beljaars, A.C.M., van de Berg, L., Bidlot, J., Bormann, N., Delsol, C., Dragani, R., Fuentes, M., Geer, A.J., Haimberger, L., Healy, S.B., Hersbach, H., Hólm, E.V., Isaksen, L., Kållberg, P., Köhler, M., Matricardi, M., McNally, A.P., Monge-Sanz, B.M., Morcrette, J.J., Park, B.K., Peubey, C., de Rosnay, P., Tavolato, C., Thépaut, J.N., Vitart, F. 2011. The ERA Interim reanalysis: Configuration and performance of the data assimilation system. Quarterly Journal of the Royal Meteorological Society 137, 553-597. Doi: 10.1002/qj.828.

Dirmeyer, P.A., Brubaker, K.L. 2007. Characterization of the global hydrologic cycle from a back trajectory analysis of atmospheric water vapor. Journal of Hydrometeorology 8, 20-37. Doi: 10.1175/JHM557.1.

Dirmeyer, P.A., Wei, J., Bosilovich, M.G., Mocko, D.M. 2014. Comparing Evaporative Sources of Terrestrial Precipitation and Their Extremes in MERRA Using Relative Entropy. Journal of Hydrometeorology 15, 102-116. Doi: 10.1175/JHM-D-13-053.1.

Drumond, A., Marengo, J., Ambrizzi, T., Nieto, R., Moreira, L., Gimeno, L. 2014. The role of the Amazon Basin moisture in the atmospheric branch of the hydrological cycle: A Lagrangian analysis. Hydrology and Earth System Sciences 18, 2577-2598. Doi: 10.5194/hess-18-25772014.

Drumond, A., Nieto, R., Gimeno, L., Trigo, R.M., Ambrizzi, T., De Souza, E. 2010. A Lagrangian identification of the sources of moisture over Northeastern Brazil during its pre-rainy and rainy seasons. PLOS ONE 5 (6), e11205. Doi: 10.1371/journal.pone.0011205.

Drumond, A., Nieto, R., Gimeno, L., Ambrizzi, T. 2008. A lagrangian identification of major sources of moisture over Central Brazil and La Plata Basin. Journal of Geophysical Research 113, D14128. Doi: 10.1029/2007JD009547.

Feng, S., Hu, Q., Robert, J. 2010. Influence of Atlantic sea surface temperatures on persistent drought in North America. Climate Dynamics. Doi: 10.1007/s00382-010-0835-x. 
Gimeno, L., Nieto, R., Drumond, A., Castillo, R., Trigo, R.M. 2013. Influence of the intensification of the major oceanic moisture sources on continental precipitation. Geophysical Research Letters. Doi: 10.1002/grl.50338.

Gimeno, L., Stohl, A., Trigo, R.M., Dominguez, F., Yoshimura, K., Yu, L., Drumond, A., DuránQuesada, A.M., Nieto, R. 2012. Oceanic and Terrestrial Sources of Continental Precipitation. Reviews of Geophysics 50, RG4003. Doi: 10.1029/2012RG000389.

Gimeno, L., Drumond, A., Nieto, R., Trigo, R.M., Stohl, A. 2010. On the origin of continental precipitation. Geophysical Research Letters 37, L13804. Doi: 10.1029/2010GL043712.

Kam, J., Sheffiled, J., Wood, E. 2014. A multi-scale analysis of drought and pluvial mechanisms for the Southeastern United States. Journal of Geophysical Research. Doi: 10.1002/2014JD021453.

Knippertz, P., Wernli, H., Glaser, G. 2013. A global climatology of tropical moisture. Journal of Climate 26, 3031-3045. Doi: 10.1175/JCLID-12-00401.1.

MacDonald, G.M. 2010. Water, climate change, and sustainability in the southwest. Proceedings of the National Academy of Science 107, 21256-21262,. Doi: 10.1073/pnas.0909651107.

McKee, T.B.N., Doesken, J., Kleist, J. 1993. The relationship of drought frequency and duration to time scales. Eight Conference on Applied Climatology. American Meteorological Society, Anaheim, CA, pp. 179-184.

Miralles, D.G., Teuling A.J., van Heerwaarden, C.C., de Arellano, J.V.G. 2014. Mega-heatwave temperatures due to combined soil desiccation and atmospheric heat accumulation. Nature Geosciences 7, 345-349. Doi: 10.1038/ngeo2141.

Nieto, R., Castillo, R., Drumond, A. 2014. The modulation of oceanic moisture transport by the hemispheric annular modes. Frontiers in Earth Sciences 1-12. Doi: 10.3389/feart.2014.00011.

Nieto, R., Gimeno, L., Trigo, R.M. 2006. A Lagrangian identification of major sources of Sahel moisture. Geophysical Research Letters 33, L18707. Doi: 10.1029/2006GL027232.

Numaguti, A. 1999. Origin and recycling processes of precipitating water over the Eurasian continent: Experiments using an atmospheric general circulation model. Journal of Geophysical Research: Atmospheres 104, 1957-1972. Doi: 10.1029/1998JD200026.

Palmer, W.C. 1965. Meteorological droughts. U.S. Department of Commerce Weather Bureau Research Paper 45, 58 pp.

Seneviratne, S.I., Lüthi, D., Litschi, M., Schär, C. 2006. Land-atmosphere coupling and climate change in Europe. Nature 443, 205-209. Doi: 10.1038/ nature05095.

Sodemann, H., Schwierz, C., Wernli, H. 2008. Interannual variability of Greenland winter precipitation sources: Lagrangian moisture diagnostic and North Atlantic Oscillation influence. Journal of Geophysical Research: Atmospheres 113, D12, 27. Doi: 10.1029/2007JD009416.

Sousa, P., Trigo, R.M., Aizpurua, P., Nieto, R., Gimeno, L., Garcia-Herrera, R. 2011. Trends and extremes of drought indices throughout the 20th century in the Mediterranean. Natural Hazards and Earth System Sciences 11, 33-51. Doi: 10.5194/nhess-11-33-2011.

Stohl, A., James, P. 2004. A Lagrangian Analysis of the Atmospheric Branch of the Global Water Cycle. Part I: Method Description, Validation and Demonstration for the August 2002 Flooding in Central Europe. Journal of Hydrometeorology 5, 656-678. Doi: 10.1175/15257541.

Stohl, A., James, P. 2005. A Lagrangian analysis of the atmospheric branch of the global water cycle. Part II. Moisture transports between Earth's ocean basins and river catchments. Journal of Hydrometeorology 6, 961-984. Doi: 10.1175/JHM470.1.

Trenberth, K.E., Fasullo, J.T., Mackaro, J. 2011. Atmospheric moisture transports from ocean to land and global energy flows in reanalyses. Journal of Climate 24 (18), 4907-4924. Doi: 10.1175/2011jcli4171.1. 
Trenberth, K.E., Guillemot, C.J. 1998. Evaluation of the atmospheric moisture and hydrological cycle in the NCEP/NCAR reanalysis. Climate Dynamics 14, 213-231. Doi: 10.1007/ s003820050219.

Trigo, R.M., Añel, J.A., Barriopedro, D., Garcia-Herrera, R., Gimeno, L., Nieto, R., Castillo, R., Allen, M.R., Massey, N. 2013. The record winter drought of 2011-2012 in the Iberian Peninsula. Bulletin of the American Meteorological Society 94 (9), S41-S45.

Vicente-Serrano, S.M., Beguería, S., López-Moreno, J.I. 2010. A multiscalar drought index sensitive to global warming: The standardized precipitation evapotranspiration index SPEI. Journal of Climate 23 (7), 1696-1718. Doi: 10.1175/2009JCLI2909.1.

Vicente-Serrano, S.M. 2004. Evolución espacio-temporal de las sequías en el sector central del valle del Ebro: causas y consecuencias ambientales. Universidad de Zaragoza, Zaragoza, $1258 \mathrm{pp}$. 